\author{
Agnieszka Alińska \\ Szkoła Główna Handlowa w Warszawie \\ e-mail: aalin@sgh.waw.pl
}

\title{
ARCHITEKTURA I PRZYCZYNY ZMIAN \\ ORGANIZACYJNYCH W SEKTORZE BANKOWYM W UNII EUROPEJSKIEJ
}

\author{
ARCHITECTURE AND CAUSES \\ OF ORGANIZATIONAL CHANGES \\ IN THE BANKING SECTOR \\ IN THE EUROPEAN UNION
}

DOI: $10.15611 /$ pn.2018.531.01
JEL Classification: G21, G23

Streszczenie: Zmiany struktur organizacyjnych w bankach są zjawiskiem wynikającym z nowych strategii działania, determinowane przede wszystkim uwarunkowaniami zewnętrznymi oraz zasobami, w jakie wyposażone są instytucje bankowe. Celem niniejszego artykułu jest analiza skali zmian instytucjonalnych w systemach bankowych i wskazanie przyczyn oraz konsekwencji rynkowych wynikających z wprowadzenia nowych strategii działania w zakresie ich struktur organizacyjnych. W opracowaniu zostanie wykorzystana metoda desk research, a na jej podstawie przeprowadzone wnioskowanie teoretyczne pozwalające na udzielenie odpowiedzi na pytanie: Jak zmiany w zakresie stosowanych strategii rozwiązań instytucjonalnych wpłyną na stworzenie nowej architektury systemu bankowego? Ponadto zostaną wykorzystane metody analizy przyczynowo-skutkowej i analizy szeregów czasowych.

Słowa kluczowe: banki, struktury organizacyjne, FinTech.

Summary: Changes in organizational structures in banks are a phenomenon resulting the new operating strategies, determined primarily by external conditions and resources that banking institutions are equipped with. Adaptation to the challenges and needs of customers and banks supervisors is reflected in the business profile of banks, looking for the most secure, profitable and optimal solutions for the scope and scale of their operations. The purpose of this article is to analyze the scale of institutional changes in banking system and identify the causes and market consequences after introduction of new action strategies and changes in their organizational structures. The study uses the method of desk research and theoretical inference allowing answering the question: how does changes in the strategies of banking institutions could cause the creation of a new banking system architecture? In addition, methods of cause-and-effect analysis and time series analysis will be used.

Keywords: banks, organizational structures, FinTech. 


\section{Wstęp}

System finansowy jest dynamicznie rozwijającym się sektorem gospodarki, który dostosowuje się do zmieniających się potrzeb klientów i uwarunkowań występujących w jego otoczeniu. W ostatniej dekadzie pojawiało się wiele czynników, które przyczyniły się do konieczności wprowadzania zmian instytucjonalnych w wewnętrznej organizacji banków i miały wpływ na ogólny (zewnętrzny) obraz ich struktury organizacyjnej. Wśród podstawowych przyczyn zmian dokonywanych w strukturach organizacyjnych banków wymienić należy przede wszystkim:

I. Kryzys finansowy i jego skutki, które przejawiają się w trzech zasadniczych obszarach: (1) spadku aktywności gospodarczej wśród klientów banków, (2) środowisku niskich stop procentowych, (3) nowych wymogach ostrożnościowych wprowadzonych przez władze nadzorcze w odpowiedzi na ryzyko systemowe w sektorze bankowym;

II. Realizację wewnętrznych strategii działania opartych na fuzjach, konsolidacjach i przejęciach, których celem jest przede wszystkim ograniczenie kosztów transakcyjnych. Przykładem tego typu działania jest decyzja Rabobanku w zakresie konsolidacji grupy;

III. Zmiany w preferencjach i przyzwyczajeniach klientów;

IV. Pojawienie się na rynku nowych, konkurencyjnych podmiotów (najczęściej FinTech), które opierają swoją działalność na wykorzystaniu digitalizacji jako formy kontaktu $\mathrm{z}$ klientem, co w efekcie wpływa na zmianę formy pośrednictwa na rynku usług finansowych.

Celem niniejszego artykułu jest analiza skali zmian instytucjonalnych w strukturach banków i wskazanie przyczyn oraz konsekwencji rynkowych wynikających $\mathrm{z}$ wprowadzenia nowych strategii w zakresie ich struktur organizacyjnych.

Identyfikacja skali dotychczas wprowadzony zmian i określenie dalszych kierunków rozwoju sektora bankowego w Europie wskazuje, że podejmowane działania służą przede wszystkim ograniczaniu kosztów i optymalizacji prowadzonej działalności zgodnie z potrzebami klientów banków. Nie mniejsze znaczenie w implementacji zmian organizacyjnych przypisać należy także nowym wymogom władz nadzorczych, które dbają o stabilność i bezpieczeństwo systemu finansowego. Ponadto okazuje się jednak, że nie tylko wymogi regulacyjne nakładane na banki po kryzysie oraz dążenie do zachowania bezpieczeństwa ich funkcjonowania na rynku usług finansowych wymuszają konieczność poszukiwania nowych rozwiązań organizacyjnych. Na znaczeniu zyskuje coraz większa konkurencja ze strony niebankowych instytucji finansowych, które wykorzystują najnowsze rozwiązania technologiczne w celu dostarczania usług finansowych i uzyskania przewagi konkurencyjnej. Dostosowanie się do powyższych wyzwań oraz potrzeb otoczenia znajduje swoje odzwierciedlenie w zmianach profilu biznesowego banków, które poszukują rozwiązań optymalnych, bezpiecznych i dochodowych. 


\section{Identyfikacja przyczyny zmian organizacyjnych sektora bankowego}

Zmiany społeczne, gospodarcze i technologiczne a przede wszystkim kryzys finansowy i jego skutki determinują konieczność zmian w wielu obszarach aktywności gospodarczej. Czynniki te nie pozostały obojętne także dla systemu finansowego, w tym przede wszystkim dla sektora bankowego w Europie. Banki, uzyskując niższe stopy zwrotu z zainwestowanych kapitałów i uzyskując słabsze wskaźniki w zakresie oceny efektywności ich funkcjonowania, wprowadzają rozwiązania, których celem było (i w dalszym ciągu jest) uzyskanie stabilnego, zrównoważonego i długoterminowego rozwoju.

Mikroekonomicznych uwarunkowań i przyczyn zmian w wewnętrznej organizacji banków jest wiele. Najogólniej można je podzielić na te, które są związane z realizacją celów (1) interesariuszy i (2) właścicieli. Cechą wspólną dla tych dwóch grup celów jest potrzeba zbudowania sprawnie działającej i dochodowej struktury organizacyjnej. Instytucje bankowe, które opierają swoją działalność na zaufaniu publicznym, poszukują elementów przewagi rynkowej i realizacji takich strategii działania, które pozwolą im na wykorzystanie posiadanych zasobów i poprawę uzyskiwanych wyników.

Z kolei wśród podstawowych makroekonomicznych i sektorowych przyczyn zmian w strukturach organizacyjnych banków wymienić należy przede wszystkim kryzys finansowy, który miał także swoje konsekwencje dla sfery realnej gospodarki. Przejawiał się on przede wszystkim w ograniczeniu aktywności banków w zakresie finansowania potrzeb przedsiębiorstw i gospodarstw domowych, co miało swoje przełożenie na wartości podstawowych parametrów makroekonomicznych, jak np. PKB. Oprócz spowolnienia gospodarczego w wielu krajach UE odpowiedzią na kryzys było także wprowadzenie nowych, bardziej rygorystycznych regulacji, które spowodowały wzrost wymogów w zakresie zgromadzenia dodatkowych kapitałów czy spełnienia wymogów ostrożnościowych. To z kolei determinowało konieczność podjęcia dodatkowych działań restrukturyzacyjnych, które najczęściej związane były z optymalizacją rozwiązań organizacyjnych w strukturach bankowych. Powyższe czynniki i uwarunkowania wskazują, że globalny kryzys finansowy spowodował istotne zmiany $\mathrm{w}$ funkcjonowaniu i organizacji zarówno systemu finansowego w ujęciu sektorowym, jak i na poziomie poszczególnych instytucji bankowych.

Kolejną zasadniczą przyczyną zmian w strukturach organizacyjnych są decyzje właścicieli o dokonaniu fuzji i przejęcia w systemie bankowym. Wśród motywów fuzji wymienia się przede wszystkim [Szczepankowski 2000; Lewandowski i in. 2001]:

a) korzyści techniczno-operacyjne, jak np. synergia operacyjna, zwiększenie efektywności zarządzania czy korzyści skali, a przy tym ograniczenie kosztów transakcyjnych, 
b) korzyści rynkowo-marketingowe, jak np. zwiększenie udziału w rynku, wzrost wartości dodanej banku, wyeliminowanie konkurentów, dywersyfikacja ryzyka czy komplementarność produktów,

c) korzyści finansowo-ekonomiczne, jak np. obniżenie kosztów pozyskiwania kapitałów, wyższa rentowność czy ograniczenia kosztów,

d) motywy menedżerskie wynikające ze zmniejszenia ryzyka zarządzania czy wzrostu swobody działania.

Oprócz przyczyn zmian w strukturach organizacyjnych banków wywołanych konsekwencjami kryzysu finansowego i decyzjami ich właścicieli duże znaczenie przywiązuje się do nowych preferencji i przyzwyczajeń klientów banków. Tradycyjne pośrednictwo finansowe kojarzy się najczęściej z fizyczną wizytą w danej instytucji i bezpośrednim kontaktem z doradcą bankowym. Strategia taka wiąże się jednak z wysokimi kosztami, jakie musi ponieść pośrednik finansowy, by zapewnić swoim klientom usługi zaspokajające ich potrzeby w preferowanej formie. Dynamiczny wzrost dostępu do Internetu i telefonii komórkowej spowodował, że potrzeby klientów uległy istotnej zmianie i w większym zakresie wykorzystują oni kanały bankowości mobilnej i elektronicznej.

Z danych Eurostatu wynika, że wykorzystanie elektronicznych i mobilnych kanałów komunikacji społecznej w Unii Europejskiej systematycznie wzrasta. Polska na tle państw UE pozycjonuje się poniżej średniej (39\% w stosunku do 49\% w UE (28) w zakresie korzystania przez osoby w wieku 16-74 lat z usług bankowości internetowej, szczególnie w porównaniu z takimi państwami, jak Norwegia czy Dania, gdzie udział społeczeństwa korzystającego z bankowości internetowej wynosi odpowiednio $91 \%$ i $88 \%$.

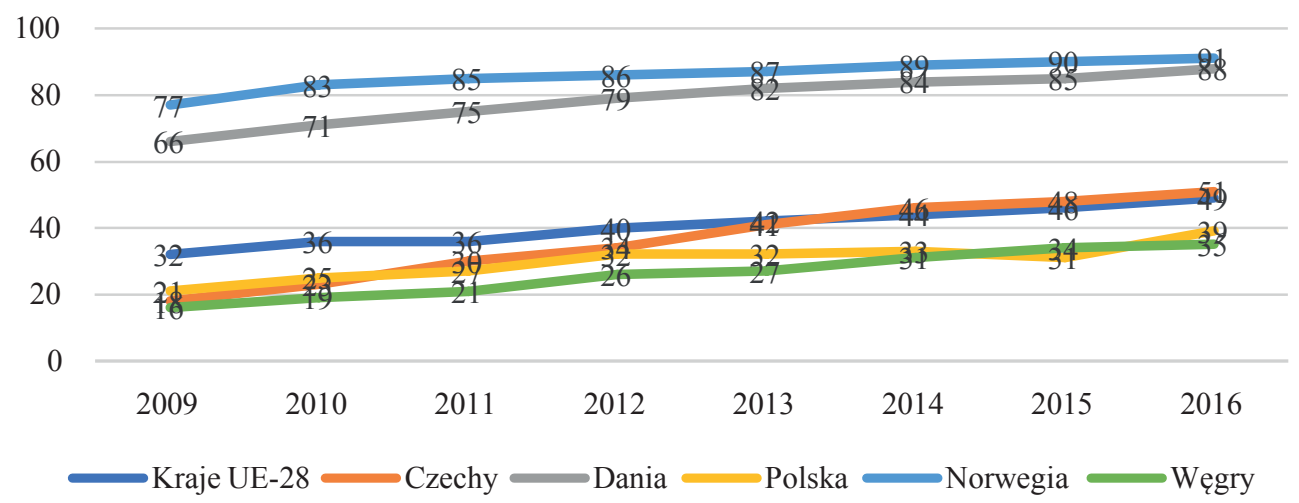

Rys. 1. Udział osób (w wieku 16-74 lat) korzystających z bankowości internetowych w wybranych krajach UE (w\%)

Źródło: opracowanie własne na podstawie danych Eurostatu. 
Z badań przeprowadzonych na zlecenie NBP [Maison 2017] wynika, że w Polsce w latach 2009-2016 także zwiększył się udział osób aktywnie korzystających z konta internetowego (wzrost z 46\% do 69\%). Jednocześnie spadł odsetek osób częściej korzystających z oddziałów banku (spadek z 30\% do 8\%). Wraz z rozwojem usług bankowości internetowej obserwujemy wzrost liczby osób korzystających w Polsce z usług bankowości mobilnej. Na koniec 2016 r. ponad 7,6 mln osób było użytkownikiem tego rodzaju usług finansowych.

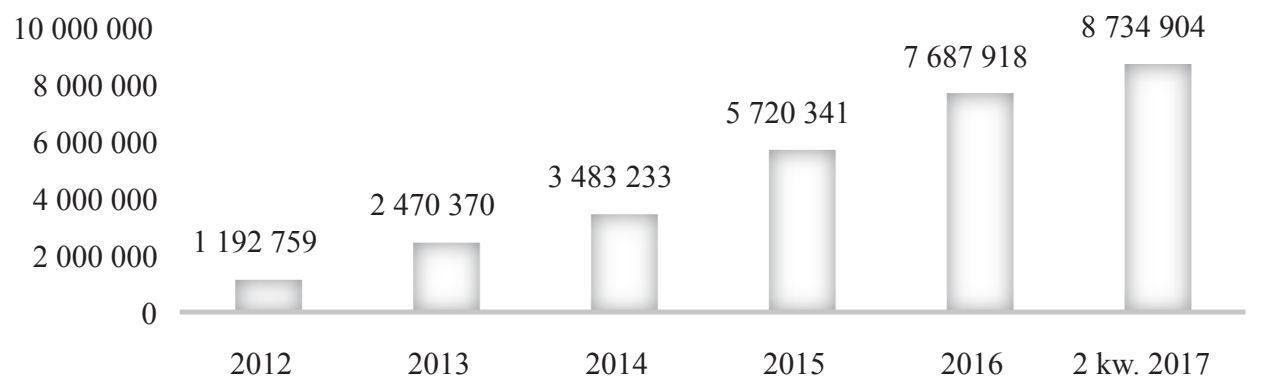

Rys. 2. Liczba użytkowników bankowości mobilnej w Polsce

Źródło: opracowanie własne na podstawie danych ZBP.

Blisko 40\% społeczeństwa w Polsce, które aktywnie korzysta z usług bankowości internetowej, ma możliwość szerszego korzystania z oferty banków w tym zakresie, gdyż ponad 33 mln osób w Polsce ma dostęp do Internetu.

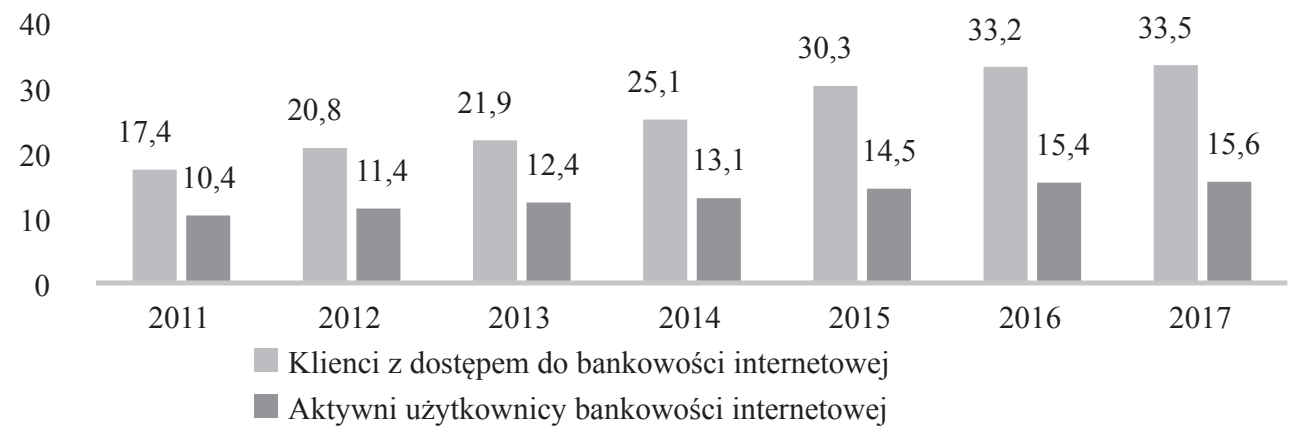

Rys. 3. Liczba klientów z dostępem do bankowości internetowej i aktywnych użytkowników bankowości internetowej w Polsce (w mln)

Źródło: opracowanie własne na podstawie danych ZBP.

Zmiany w zakresie preferencji i potrzeb klientów będą wpływały na zmiany w strukturze zarówno wartości generowanych przychodów, jak i kosztów instytucji bankowych. Według ekonomistów McKinseya [2015] w przyszłości obserwo- 
wać będziemy dalszy dynamiczny wzrost udziału wydatków związanych z automatyzacją usług i wykorzystaniem technologii cyfrowych do tworzenia nowych produktów i usług finansowych. Instytucje, które zdecydują się na wprowadzenie cyfrowych innowacji, mogą liczyć na dodatni efekt w postaci korzyści i wyższych przychodów, szacowanych w przyszłości na poziomie ok. 45\% zysku netto. Korzyści te wynikać będą przede wszystkim z:

- wzrostu przychodów z tytułu nowych ofert i innowacyjnego modelu biznesowego $(+5 \%)$;

- wzrostu przychodów z tytułu nowych produktów sprzedaży w formie on-line oraz sprzedaży usług i produktów w formie cross-sellingu (sprzedaży krzyżowej) $(+10 \%)$;

- niższych kosztów operacyjnych (migracje transakcji, automatyzacja) (+30\%).

Z kolei zagrożenia związane będą przede wszystkim z kosztami generowanymi w zakresie:

- wprowadzania nowych innowacyjnych ofert $(-13 \%)$;

- $\quad$ spadku marży $(-16 \%)$;

- wzrostu ryzyka operacyjnego $(-6 \%)$.

O ile trzy pierwsze przyczyny zmian w organizacji i zarządzaniu instytucjami bankowymi pozostają niezwykle ważne, to jednak priorytetowe znaczenie należy przypisać czynnikowi zmian, jakim jest szeroko rozumiana digitalizacja usług finansowych. Czynnik ten wpływa w pierwszej kolejności na wykorzystywanie nowych form komunikowania się banków z klientami, a następnie zmiany w formie zaspokajania ich potrzeb finansowych. Ponadto digitalizacja znacznie ułatwiła wejście na rynek nowych, niebankowych dostawców usług finansowych. Dodatkowe możliwości wynikają także z wejścia w życie od 1 stycznia 2018 r. Dyrektywy w sprawie usług płatniczych (PSD2). Wyniki analiz przeprowadzone przez McKinseya [2015] wskazują, że banki mają maksymalnie trzy do pięciu lat, aby dostosować się cyfrowo do standardów oferowanych przez niebankowe instytucje finansowe. Jednak działania w tym zakresie mogą absorbować nawet do $35 \%$ zysku netto banków. $\mathrm{Z}$ drugiej strony podkreśla się, że w ujęciu długoterminowym, po wprowadzenie rozwiązań technologicznych, banki mogą w ten sposób uzyskiwać nawet do $40 \%$ zysku. Obecnie obserwujemy, że sugestie i zalecenia firmy McKinsey już znajdują odzwierciedlenie w działaniach europejskich banków, które dostrzegają dynamiczny rozwój sektora FinTech i starają się dostosować do nowych uwarunkowań i struktury rynku usług bankowych. Według P. Schueffel [2016] FinTech to nowy sektor finansowy, który stosuje technologię w celu poprawy działalności finansowej. FinTech [FSB 2017] to także szeroko pojęte innowacje wprowadzane w sektorze finansowym, które mogą prowadzić do nowych modeli biznesowych, aplikacji, procesów lub produktów mających istotny wpływ na rynki i instytucje finansowe oraz na świadczenie usług finansowych. Cechą charakterystyczną rozwiązań FinTech jest to, że niektóre z nich mogą być autoryzowane lub zarejestrowane w ramach unijnego lub krajowego ustawodawstwa finansowego (np. na pod- 
stawie zapisów Dyrektywy PSD2) i mogą być wprowadzane samodzielnie przez banki. Jednak większość z nich nie podlega żadnym unijnym ani krajowym systemom nadzorczo-regulacyjnym związanym z systemem finansowym, gdyż jest wprowadzana na rynek przez niebankowe instytucje finansowe, które najczęściej nie podlegają władzy nadzorczej nad rynkiem finansowym. Taki stan spowodować może wzrost konkurencji na rynku usług bankowych (finansowych) i wystąpienie istotnych zmian w instytucjonalnej strukturze rynku usług finansowych.

Reasumując powyższe rozważania: wyraźnie widać zarysowujące się tendencje polegające na wykorzystaniu nowych technologii w działalności FinTech, oferowanej zarówno przez banki, jak i niebankowe instytucje finansowe. Takie zmiany świadczenia usług bankowych wpływają na zmiany w modelach biznesowych banków [Enria 2017], stosowane praktyki dystrybucji, a także na ich obecną i perspektywiczną rentowność. Instytucje nadzorcze, regulacyjne i reprezentujące sektor bankowy w UE także wskazują na istotny zakres zmian, wywołanych przede wszystkim wprowadzaniem nowych rozwiązań technologicznych z zakresu cyfryzacji, które rewolucjonizują struktury organizacyjne banków [EBA 2017].

\section{Charakterystyka zmian strukturalnych w sektorze bankowym w Unii Europejskiej}

Liczba samodzielnych banków (instytucji kredytowych w UE) w latach 2009-2016 zmniejszyła się z 8360 do 6596, co oznacza, że w tym okresie w Unii Europejskiej zaprzestały samodzielnej działalności operacyjnej 1764 banki. Najwięcej zlikwidowanych zostało w Holandii (113), Niemczech (72), Austrii (63) i Irlandii (46), tylko w Słowacji powstały 2 nowe podmioty [European Banking Federation 2018]. O skali zjawiska świadczy fakty, że tylko w jednym, 2016 roku zaprzestały działalności 453 banki, co oznacza spadek o $6 \% \mathrm{w}$ porównaniu ze stanem z roku poprzedniego. W tym samym okresie (2016 r.) oprócz central banków zlikwidowano także ponad 9 tys. placówek terenowych (co stanowiło 4,8\% ogólnej liczby oddziałów bankowych w UE). Podobne tendencje spadkowe w liczbie samodzielnie działających banków (central) występowały także w 2017 r. W tym czasie najwięcej banków zostało zlikwidowanych (poprzez fuzje i przejęcia) w Niemczech - 70, we Włoszech -65, na Węgrzech - 49 i w Austrii - 43.

W 28 krajach UE liczba oddziałów banków na koniec 2016 r. w porównaniu z rokiem 2009 zmniejszyła o 20,4\% i osiągnęła poziom 189 000, tj. o ponad 43300 oddziałów mniej. Tylko w jednym roku (2016) zlikwidowano 9100 oddziałów (tj. 4,6\%). Wraz z ograniczeniem sieci placówek terenowych w sektorze bankowym następuje ograniczenie liczby zatrudnionych w bankach. Na koniec 2016 r. liczba zatrudnionych w sektorze bankowym w UE (28) wynosiła $2,8 \mathrm{mln}$ i była niższa w porównaniu z 2009 r. o ponad $11,5 \%$. Ograniczenie zatrudnienia w sektorze bankowym nie tylko wynika z likwidacji placówek terenowych banków, ale także jest efektem zmian na poziomie centrali banku wynikających z fuzji, przejęć i likwidacji banków. 


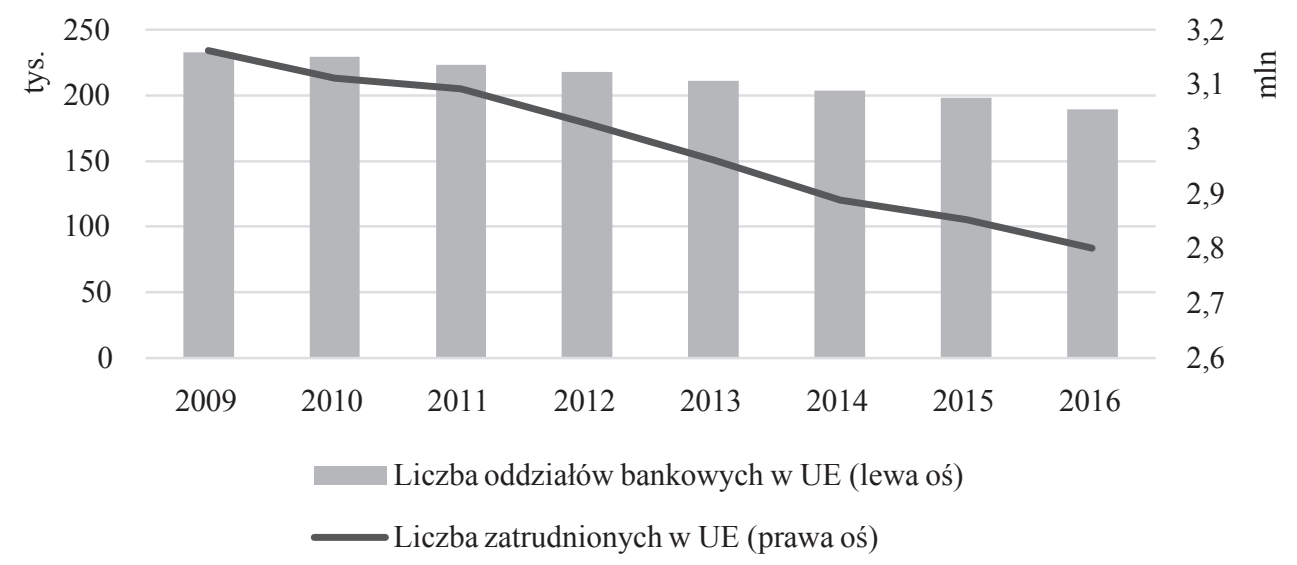

Rys. 4. Liczba terenowych placówek bankowych (oddziałów) i zatrudnionych w sektorze bankowym w 28 krajach UE

Źródło: European Banking Sector Facts \& Figures, European Banking Federation, http://www.ebf.eu/ facts_and_figures/?location=pl (10.03.2018).

Systematyczny spadek liczby banków, ich oddziałów, a jednocześnie liczby zatrudnionych w sektorze bankowym to zjawisko, które zmienia architekturę i instytucjonalną strukturę podmiotów dostarczających usług finansowych [Brush i in. 2012, s. 1499-1515]. Z przeprowadzonych badań wynika, że takie rozwiązanie jest najczęściej elementem przyjętej przez banki strategii, której celem jest przede wszystkim ograniczenie kosztów transakcyjnych i odciążenie tradycyjnych kanałów dystrybucji [Ciciretti i in. 2009, s. 81-98] na rzecz wprowadzenia rozwiązań cyfrowych i zmian w formie obsługi klientów.

Podobne do europejskich tendencje w zakresie zamian organizacyjnych występują także w USA. O ile w tym państwie w latach 2005-2008 nadwyżka liczby nowo tworzonych oddziałów bankowych przewyższała liczbę zamykanych punktów obsługi klientów, o tyle od 2009 r. tendencje rynkowe wyraźnie się zmieniły. W 2016 r. na blisko 1 tys. nowych placówek bankowych, 3 tys. zostało zlikwidowanych [Economist 2017].

Zmiany w zakresie wykorzystywanych kanałów dystrybucji usług bankowych występują nie tylko w UE, ale są także identyfikowane w Polsce. W latach 2013-2016 liczba terenowych placówek bankowych (oddziały i filie) została ograniczona o 3,2\% i na koniec 2016 r. wyniosła 168 822. W porównaniu z danymi dla UE jest to niewielka zmiana i wynika przede wszystkim z dużego udziału sektora bankowości spółdzielczej w strukturze terenowych placówek bankowych w Polsce. Udział tego sektora w rynku wynosi $38,8 \%$ i jest przykładem działalności opartej na strategii wykorzystującej relacyjny model obsługi klienta. W grudniu 2016 r. liczba placówek (łącznie z centralami) w sektorze banków spółdzielczych w Polsce była mniejsza o 123 w porównaniu z grudniem 2015 r. i wynosiła 4602. Przecięt- 
ne zatrudnienie w centralach tych banków wyniosło 26,5 etatu, w pozostałych zaś placówkach terenowych 4,1 etatu. Zmiany w sektorze bankowym, z którymi mamy do czynienia w zakresie organizacyjnym, znajdują odzwierciedlenie w stanie zatrudnionych w tym sektorze w Polsce. W latach 2010-2017 liczba zatrudnionych w Banku Handlowym zmniejszyła się z 6 tys. osób do 3,5 tys. osób. W całym sektorze bankowym w Polsce w latach 2010-2017 liczba zatrudnionych spadła o 10,3 tys. osób - do 166 tys. osób. Dotyczy to przede wszystkim oddziałów, gdzie ze względu na likwidacje placówek pracownicy zostali zwolnieni.

Struktura organizacyjna sektora bankowego w Polsce na tle UE zaliczana jest do grupy silnie rozbudowanej. Pracownicy zatrudnieni w sektorze bankowym w Polsce (173 043) stanowili 6,2\% ogólnego zatrudnienia w UE (28). Jest to efekt stosunkowo dużej liczby banków spółdzielczych, które są samodzielnymi podmiotami bankowymi. Udział banków z Polski w sektorze bankowym na koniec 2016 r. wynosił ponad 10,1\%. Silnie rozbudowana struktura organizacyjna sektora bankowego w Polsce wiąże się z koniecznością zatrudnienia pracowników w tym sektorze. Biorąc od uwagę, że udział sektora bankowego w Polsce w europejskim sektorze bankowym pod względem aktywów $(0,9 \%)$, kredytów $(1,2 \%)$, depozytów $(1,2 \%)$ i zgromadzonych kapitałów własnych i rezerw $(1,7 \%)$ kształtuje się na poziomie ok. $1 \%$, w najbliższych latach można się spodziewać dużych zmian w tym zakresie. Zwłaszcza że w UE (podobnie jak w USA) obserwujemy znaczny spadek liczby samodzielnie funkcjonujących banków. Najwięcej, bo ponad 1/4 wszystkich banków w Unii Europejskiej zlokalizowanych jest w Niemczech.

Reasumując powyższe rozważania, można stwierdzić, że odzwierciedleniem zmian w strukturach organizacyjnych poszczególnych banków i całego sektora bankowego w Unii Europejskiej jest mniejsza liczba samodzielnie funkcjonujących podmiotów i ich oddziałów terenowych, przy jednoczesnym spadku zatrudnienia. Obserwujemy, że zachodzące zmiany mają charakter dynamiczny i dotyczą przede wszystkim mniejszych banków, sektora bankowości spółdzielczej oraz tych podmiotów, które popełniły błędy w zakresie szacowania ryzyka, które zmaterializowało się w okresie kryzysu. Obraz tradycyjnego sektora bankowego ulega zmianie i raczej trudno będzie zachować dotychczasowy jego charakter.

\section{Podsumowanie}

Celem artykułu była analiza skali zmian instytucjonalnych w strukturach banków i wskazanie przyczyn oraz konsekwencji rynkowych wynikających z wprowadzenia nowych strategii w zakresie ich struktur organizacyjnych. Zaprezentowane dane świadczą przede wszystkim o zmianie tendencji, którą obserwowaliśmy w sektorze bankowym w ostatnich latach, wtedy gdy w ramach fuzji i przejęć następowało zmniejszenie liczby samodzielnie funkcjonujących banków na rzecz wzrostu sieci placówek terenowych. Obecnie tendencje zmieniły się i w ramach likwidacji samodzielnie funkcjonujących banków nie dokonuje się rozbudowy sieci placówek tere- 
nowych. Zachowania te są w pełni zrozumiałe i odzwierciedlają zmiany w zakresie zapotrzebowania, przyzwyczajeń i oczekiwań klientów dotyczących dostawców usług bankowych.

Przejawem zewnętrznych zmian organizacyjnych w zakresie instytucjonalnym wprowadzanych przez poszczególne banki jest tworząca się nowa architektura całego sektora bankowego, w ramach której obserwujemy spadek liczby oddziałów terenowych i ograniczenie liczby zatrudnionych pracowników, i w konsekwencji wzrost znaczenia usług finansowych dostarczanych przez niebankowe instytucje finansowe. Duży wpływ na skalę i zakres podejmowanych decyzji mają nowe możliwości, jakie pojawiają się na rynku usług finansowych poprzez ofertę FinTech. Banki wykorzystują własne rozwiązania technologiczne (FinTech) w zakresie nowych formuł świadczenia usług finansowych, ale także obserwujemy wzrost konkurencji ze strony niebankowych instytucji finansowych, które wykorzystują digitalizację, aby zostać trwałym ,graczem” na rynku usług bankowych. Dodatkowo wzrost dostępu do Internetu, zmiana zachowań społecznych i wzrost wymogów regulacyjnych wprowadzonych po kryzysie finansowym wpływają pozytywnie na tempo i zwiększają skalę implementacji rozwiązań opartych na wykorzystywaniu digitalizacji. Zachowania klientów na rynku usług finansowych w coraz większym stopniu determinowane są rozwojem finansowania społecznościowego. Powstawanie nowych niebankowych instytucji finansowych, np. platform społecznościowych, stanowi efekt ruchu społecznego, który powstał w odpowiedzi na wspomniane luki finansowe oraz pojawienie się nowych technologii. Zmiany zachodzące w strukturach organizacyjnych banków w Unii Europejskiej są odzwierciedleniem wpływu wielu istotnych czynników, które często mają charakter przyczynowo-skutkowy. Są one naturalnym zjawiskiem, które wynika z procesów optymalizacji funkcjonowania i dążenia do osiągnięcia korzyści. Wśród czynników identyfikowanych najczęściej największe znaczenie przypisać należy wpływowi nowych rozwiązań technologicznych, który przyczynił się do rozwoju sektora FinTech. Do tego dodać należy zmiany w oczekiwaniach ze strony klientów i wpływ pokryzysowych wymogów regulacyjnych. Ponadto zmiany w strukturach organizacyjnych banków przyczyniają się do rozwoju bankowości transakcyjnej i ograniczania bankowości relacyjnej. W tym kontekście istotne jest zidentyfikowanie przyczyn i konsekwencji zmian rynkowych, które determinować będą skalę i formy wprowadzania nowych rozwiązań organizacyjnych w bankach. Ponadto dążenie do ograniczania kosztów funkcjonowania instytucji bankowych i chęć optymalizacji wyników finansowo-ekonomicznych z jednej strony, a potrzeba zaspokajania zmieniających się potrzeb społecznych ze strony klientów - z drugiej, przyczyniły się do konieczności reorganizacji struktur bankowych i ich dostosowania do nowych warunków i wyzwań rynkowych.

Innowacje finansowe pomagają poprawić jakość i różnorodność usług bankowych, uzupełnić rynek i poprawić efektywność alokacji. W rezultacie, biorąc pod uwagę jego zyski, konieczne jest stworzenie ram prawno-organizacyjnych umożli- 
wiających ich generowanie. Należy jednak zauważyć, że cykl życia innowacji jest procesem o dużym stopniu niepewności, wywodzącym się z kilku elementów, takich jak: nowe technologie, nadzór regulacyjny i brak doświadczeń w organizacji, identyfikacji potencjalnych zagrożeń lub nieznanych wymogów prawnych.

\section{Literatura}

Brush T.H., Dangol R., O'Brien J.P., 2012, Customer capabilities, switching costs, and bank performance, Strategic Management Journal, no. 33.

CBR, 2015, European bank IT spending gaining momentum by 2017, http://www.cbronline.com/news/ european-bank-it-spending-gaining-momentum-by-2017-4511839/.

Ciciretti R., Hasan I., Zazzara C., 2009, Do Internet activities add value? Evidence from the traditional banks, Journal of Financial Services Research, vol. 35(1).

EBA, 2017, Discussion Paper on the EBA's approach to financial technology (FinTech), https:// www.eba.europa.eu/documents/10180/1919160/EBA+Discussion+Paper+on+Fintech+\%28EBA-DP-2017-02\%29.pdf, EBA/DP/2017/02 (25.08.2017).

Economist, 2017, The closing of American bank branches, https://www.economist.com/news/financeand-economics/21725596-banks-have-shuttered-over 10000-financial-crisis-closing-american.

Enria A., 2017, Reshaping European banks - how far have we come and what remains to done?, Danmarks Nationalbank - Networking Seminar on Economic and Financial Issues, 2017, https://www.eba.europa.eu/documents/10180/1887760/Andrea+Enria++keynote+speech+-+Danmarks+Nationalbank.pdf.

Ernst \& Young, 2016, European banks reposition for a long-term environment of low growth, http:// www.ey.com/Publication/vwLUAssets/EY-ebb-2016-infographic/\$FILE/ey-ebb-2016-infographic.pdf.

European Banking Federation, http://www.ebf.eu/facts_and_figures/?location=nl (10.04.2018).

European Commission, 2015, EU Digital Single Market: a strategy to build and sustain trust, http:// ec.europa.eu/justice/newsroom/news/150429_en.htm.

FSB, 2017, http://www.fsb.org/what-we-do/policy-development/additional-policy-areas/monitoring-of-fintech/.

Lewandowski M. i in., 2001, Fuzje i przejęcia w Polsce na tle tendencji światowych, WIG-Press, Warszawa.

Maison D., 2017, Postawy Polaków wobec obrotu bezgotówkowego, NBP, Warszawa.

McKinsey, Broeders H., Khanna S., 2015, Strategic choices for banks in the digital age, http://www. mckinsey.com/industries/financial-services/our-insights/strategic-choices-for-banks-in-the-digital-age.

Schueffel P., 2016, Taming the beast: a scientific definition of FinTech, Journal of Innovation Management, no. 4, s. 32-54.

Szczepankowski P., 2000, Fuzje i przejęcia, PWN, Warszawa, 